\title{
PHYTOMONITORING OF BRICK KILN INDUCED AIR POLLUTION AT KONABARI OF BANGLADESH
}

\author{
Tanmoy Roy Tusher $^{1 *}$, Shilpi Akter ${ }^{1}$, Zisan Ashraf ${ }^{1}$, Md. Humayun Kabir ${ }^{1}$ and Md. \\ Nurealam Siddiqui ${ }^{2}$ \\ ${ }^{1}$ Department of Environmental Science and Resource Management, Mawlana Bhashani Science and Technology \\ University, Tangail-1902, Bangladesh \\ ${ }^{2}$ Department of Biochemistry and Molecular Biology, Bangabandhu Sheikh Mujibur Rahman Agricultural \\ University, Gazipur-1706, Bangladesh \\ *Corresponding author's email: tusrroy@ yahoo.com



DOI: https://doi.org/10.22452/mjs.vol37no1.4

\begin{abstract}
The study was conducted to assess the effects of brick kiln induced air pollution on the surrounding vegetation as a function of distance at Baghiya of Konabari union in Gazipur district of Bangladesh. Four samples of two indigenous (Mangifera indica and Artocarpus heterophyllus) and two exotic (Eucalyptus camaldulensis and Acacia auriculacformis) plant species, mostly common in the study area, were collected from three sampling stations (southwest of brick kilns following the prevailing wind) which were $200 \mathrm{~m}$ away from each other to analyze total chlorophyll, $\mathrm{Na}^{+}, \mathrm{K}^{+}, \mathrm{K}^{+} / \mathrm{Na}^{+}$ratio, total sugar and proline contents. The study observed that a reduction in total chlorophyll, $\mathrm{Na}^{+}$and total sugar contents in the leaf samples of all sampled plant species at SS-1 (near source station) when compared to the samples at SS-3 (distant station). The study found that indigenous plant species were more sensitive in case of the total chlorophyll content, whereas exotic plant species were more sensitive in case of total sugar content. At SS-1, the lower value of $\mathrm{K}^{+}$content and higher value of $\mathrm{K}^{+} / \mathrm{Na}^{+}$ratio were found in all plant species than at SS-3 except E. camaldulensis and A. auriculacformis, respectively. The lower level of proline content was observed in $M$. indica $(240.00 \mu \mathrm{g} / \mathrm{g})$ and A. heterophyllus $(249.05 \mu \mathrm{g} / \mathrm{g})$ at SS-1, whereas the higher level of proline content was found in E. camaldulensis (388.00 $\mu \mathrm{g} / \mathrm{g}$ ) and A. auriculacformis (354.09 $\mu \mathrm{g} / \mathrm{g}$ ) at SS-1 when compared to SS-3 which indicated that the more sensitivity of indigenous plant species to air pollution than exotic plant species. Monitoring of existing kilns and strictly following of brick kiln related rules and regulations in installing new kilns is, thus, necessary for minimizing the impacts of air pollution in the study area.
\end{abstract}

Keywords: Phytomonitoring, brick kiln, air pollution, indigenous and exotic species.

\section{INTRODUCTION}

Brickfields are identified as a vital air pollutant source and also considered as the important contributors to the greenhouse gases emission in the major cities of Bangladesh (Ahmmed \& Begum, 2010; Darain et al., 2013). The most important 
pollutants emitted from brick-making kilns operations in the dry season are carbon monoxide (CO), sulfur dioxide $\left(\mathrm{SO}_{2}\right)$, nitrogen oxides $\left(\mathrm{NO}_{\mathrm{x}}\right)$, ozone $\left(\mathrm{O}_{3}\right)$, hydrocarbons (HC) and suspended particulate matter (SPM) (Ahmmed \& Begum, 2010; Maatoug, 2010). In Bangladesh, the brick kiln industry is one of the fastest-growing sectors with current manufacturing capacity of 12 billion bricks a year from 4500 brick kilns surrounding all major cities of Dhaka, Khulna, Rajshahi and Chittagong, and expected to grow $50 \%$ by 2020 (WB, 2007; UNDP, 2011). A significant factor is that brick kilns are usually clustered near big cites in different parts of Bangladesh (Ahmed \& Hossain, 2008). The design of kilns, fuel characteristics and lack of complete combustion and emission control contribute to the release of contaminants and high concentration of pollutants from brick kilns in the form of flue gases (Fatima, 2011). Although, brick-kiln industry plays a major role in providing building material, its role in polluting air quality can never be ignored. With a rapid but uncontrolled development, emission from these sources is constantly increased and adversely affecting the environment (Hassan et al., 2012).

The plants act as sink for pollutants as they are continuously exposed to polluted air (Pathak et al., 2015). Plants provide an enormous leaf area for impingement, absorption and accumulation of air pollutants to reduce the pollutant level in the air environment, with a various extent for different species (Liu \& Ding, 2008). The use of plants as monitors of air pollution has long been established and plants show several changes in morphology, physiology, anatomy, and biochemistry of leaves in polluted area (Gupta et al., 2012). The air pollutants negatively affect the vegetation in terms of foliar injury, physiological and biochemical alterations (Kainulainen et al., 1995; Prakesh et al., 2002). Chauhan (2008) and Chauhan \& Joshi (2010) studied the effects of ambient air pollutants, $\mathrm{NOx}, \mathrm{SO}_{2}$ and particulate pollutants, on some crops grown in the urban and industrial areas of Haridwar city and observed that the gaseous $\left(\mathrm{SO}_{2}\right.$ and $\left.\mathrm{NOx}\right)$ and particulate pollutants have detrimental effects on the crops through changes in morphological characteristics, photosynthetic pigments and yield of crops.

Though the largest clusters of brick kilns are located in Gazipur with approximately 320 kilns (GEF-UNDP, 2006), air pollutants emitting from these kilns may have adverse impacts on surrounding vegetation of the area. Since Bhawal Garh is situated at Gazipur (Banglapedia, 2013) and air pollutants can travel thousands of miles (Yadav et al., 2013), these air pollutants may destroy the whole Bhawal forest ecosystem in long run, which in turn can create an environmental menace (Rahman et al., 2010). Thus, it is necessary to make an experimental study based on the impacts of brick field clusters which have serious air pollution problems on surrounding vegetation. Considering these, the study was performed to assess the effects of brick kiln induced air pollution on the physiological parameters (total chlorophyll, $\mathrm{Na}^{+}, \mathrm{K}^{+}, \mathrm{K}^{+} / \mathrm{Na}^{+}$ratio, total 
sugar, and proline contents) of surrounding vegetation in the downwind areas as a function of distance.

\section{MATERIALS AND METHODS}

\section{Study area}

The study was conducted at Baghiya of Konabari union in Gazipur sadar upazila which was approximately at the latitude $24^{\circ} 01^{\prime} 40.00^{\prime \prime} \mathrm{N}$ and longitude $90^{\circ} 20^{\prime} 05.05^{\prime \prime}$ E (Fig. 1). The elevation of the study area was approximately $10 \mathrm{~m}$ (Banglapedia, 2013). The study area is a part of the largest brick kiln cluster of Bangladesh located in
Gazipur where approximately 320 kilns are in operation, each consisting of 200-300 daily wage workers per kiln (GEF-UNDP, 2006; WB, 2007). A total of three stations were taken as sampling stations around the brick kiln area. The station 1 (SS-1) was located nearby to the kiln periphery. The rest of the stations (SS-2 and SS-3) were taken as a function of distance i.e. going downwind (southwest) from the stations 1 , and were approximately $200 \mathrm{~m}$ away from each other. The SS-1 was considered as near source station, whereas SS-2 and SS-3 were considered as distant station.

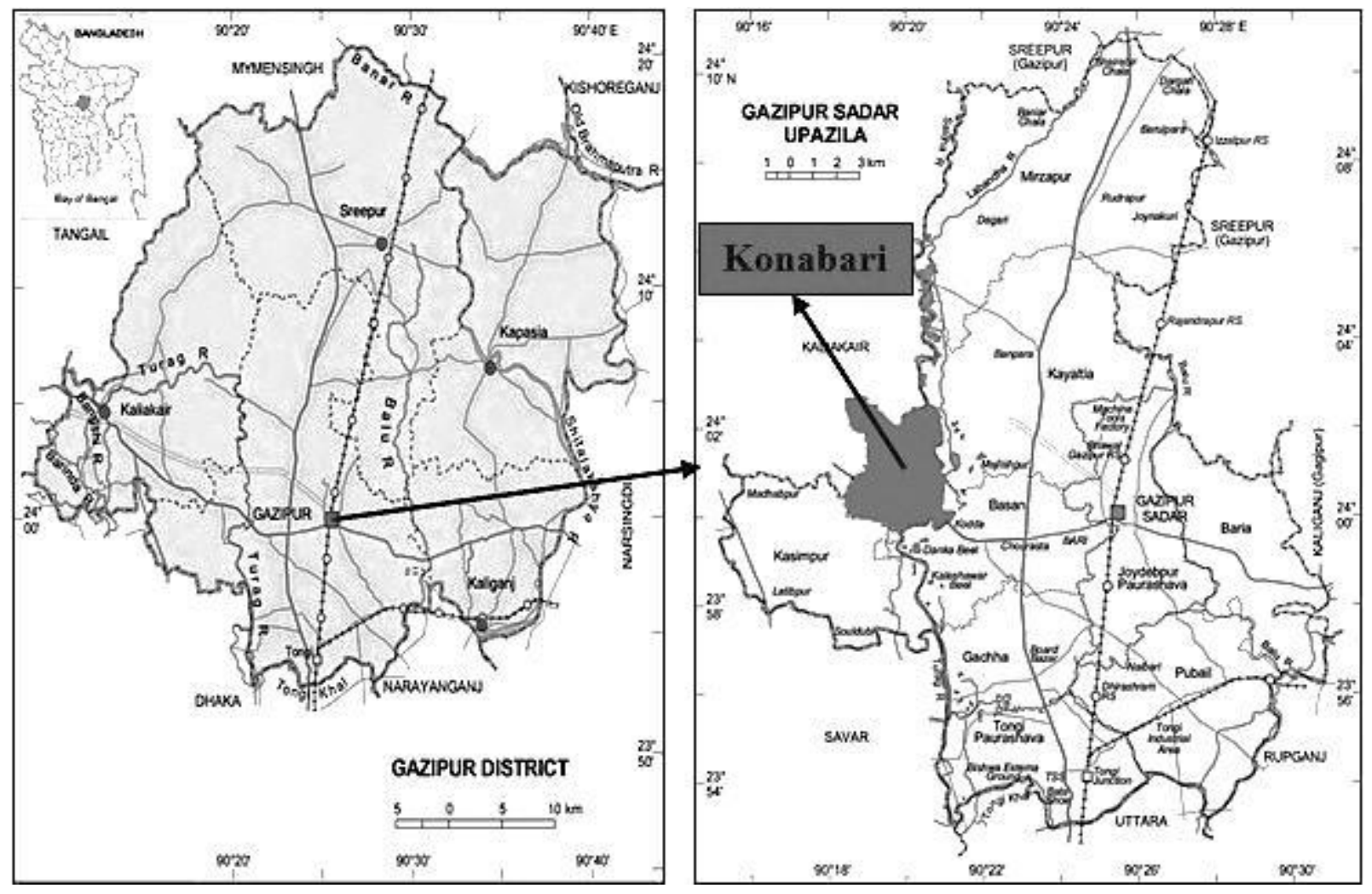

Fig. 1. Map showing the study area of Konabari in Gazipur sadar upazila (Banglapedia, 2013). 


\section{Sample collection}

From three sampling stations, four common plant species including two indigenous (Mangifera indica and Artocarpus heterophyllus) and two exotic (Eucalyptus camaldulensis and Acacia auriculacformis) species were selected and sampled considering matured leaves from each matured tree species during the month of February 2015. Samples were placed in sealed polythene bags and lebeled including date of collection, location and code number of leaf sample. The details of plant leaf samples with their corresponding sampling stations are given in Table 1.

Table 1. Description of leaf samples with their corresponding sampling stations.

\begin{tabular}{lccc}
\hline Plant Species & $\begin{array}{c}\text { Sample } \\
\text { ID }\end{array}$ & $\begin{array}{c}\text { Sampling } \\
\text { Stations }\end{array}$ & $\begin{array}{c}\text { Location of the } \\
\text { Sampling Stations }\end{array}$ \\
\hline Scientific name: Mangifera indica & MiS1 & SS-1 & At kiln periphery (0 m) \\
Local name: Aam & MiS2 & SS-2 & 200 m from SS-1 \\
English name: Mango & MiS3 & SS-3 & 200 m from SS-2 \\
\hline Scientific name: Artocarpus heterophyllus & AhS1 & SS-1 & At kiln periphery (0 m) \\
Local name: Kathal & AhS2 & SS-2 & 200 m from SS-1 \\
English name: Jackfruit & AhS3 & SS-3 & 200 m from SS-2 \\
\hline Scientific name: Eucalyptus camaldulensis & EcS1 & SS-1 & At kiln periphery (0 m) \\
Local name: Eucalyptus & EcS2 & SS-2 & 200 m from SS-1 \\
English name: Red river gum & EcS3 & SS-3 & 200 m from SS-2 \\
\hline Scientific name: Acacia auriculacformis & AaS1 & SS-1 & At kiln periphery (0 m) \\
Local name: Akashmoni & AaS2 & SS-2 & 200 m from SS-1 \\
English name: Darwin black wattle & AaS3 & SS-3 & 200 m from SS-2 \\
\hline
\end{tabular}

\section{Sample analysis}

For the analysis of leaf physiological parameters, the samples were carried to the laboratory of the Depatment of Biochemistry and Molecular Biology, Bangabandhu Sheikh Mujibur Rahman Agricultural University, Gazipur-1706, Bangladesh. The collected plant leaf samples were analyzed to determine the total chlorophyll, $\mathrm{Na}^{+}, \mathrm{K}^{+}, \mathrm{K}^{+} / \mathrm{Na}^{+}$ratio, total sugar and proline contents. The total chlorophyll content was determined by
SPAD value (Model: MINOLTA, CHLOROPHYLL METER, SPAD-502, JAPAN). The $\mathrm{Na}^{+}$and $\mathrm{K}^{+}$contents were analyzed by EKO flame Photometer (Model FP-3B). The total sugar content was determined colorimetrically by the anthrone method (Jayaraman, 1981). The proline content was determined according to the method developed by Bates et al. (1973). 


\section{Data analysis}

The data were analyzed by using Statistical Package for Social Science (IBM SPSS Statistics 20.0) and Microsoft Office Excel 2010. For statistical treatment of data, independent samples t-test was performed to compare the effects of brick kiln induced air pollution on plant samples as a function of distance.

\section{RESULTS AND DISCUSSIONS}

Chlorophyll is an index of productivity of plant and it varies from species to species, with age of leaf and also with the pollution level as well as with other biotic and abiotic condition (Raza \& Murthy, 1988; Katiyar \& Dubey, 2001). Several studies (Kainulainen et al., 1995; Prakesh et al., 2002; Chauhan \& Joshi, 2010) have reported that chlorophyll content decreases with the increase in NOx and $\mathrm{SO}_{2}$ concentration. The study investigated that the lower amount of total chlorophyll content in all sampled plant species at stations of brick kilns periphery. The total chlorophyll content was found to be depressed in the community inhabiting SS-1 including all sampled plant species than at SS-3 ( $p=0.203 ; p>0.05)$ which clearly revealed that the reduction of chlorophyll content with increasing the distance from the brick kilns (Fig. 2). In case of indigenous plant species, the observed difference between the amount of total chlorophyll content at SS-1 and SS-3 was 27.1 and $29.0 \%$ in Mangifera indica and Artocarpus heterophyllus, respectively. On the other hand, in case of exotic species, the difference between the amount of total chlorophyll content at SS-1 and SS-3 was calculated only 3.2 and $7.2 \%$ in Eucalyptus camaldulensis and Acacia auriculacformis, respectively. The results of the study clearly depicted that indigenous plant species are more sensitive to air pollution, especially at near distance station, than exotic plant species.

Sodium is a functional nutrient including its requirement for maximal biomass growth for many plants (Subbarao et al., 2003). The study exhibited that air pollution significantly affects the $\mathrm{Na}^{+}$ contents $(p=0.01 ; p<0.05)$ of all sampled tree species at stations of near source of pollution (SS-1) than distant stations SS-3 (Fig. 3). Among the all plant species, the minimum value of $\mathrm{Na}^{+}$content at SS-1 was observed in Mangifera indica followed by Acacia auriculacformis, Artocarpus heterophyllus and Eucalyptus camaldulensis. 


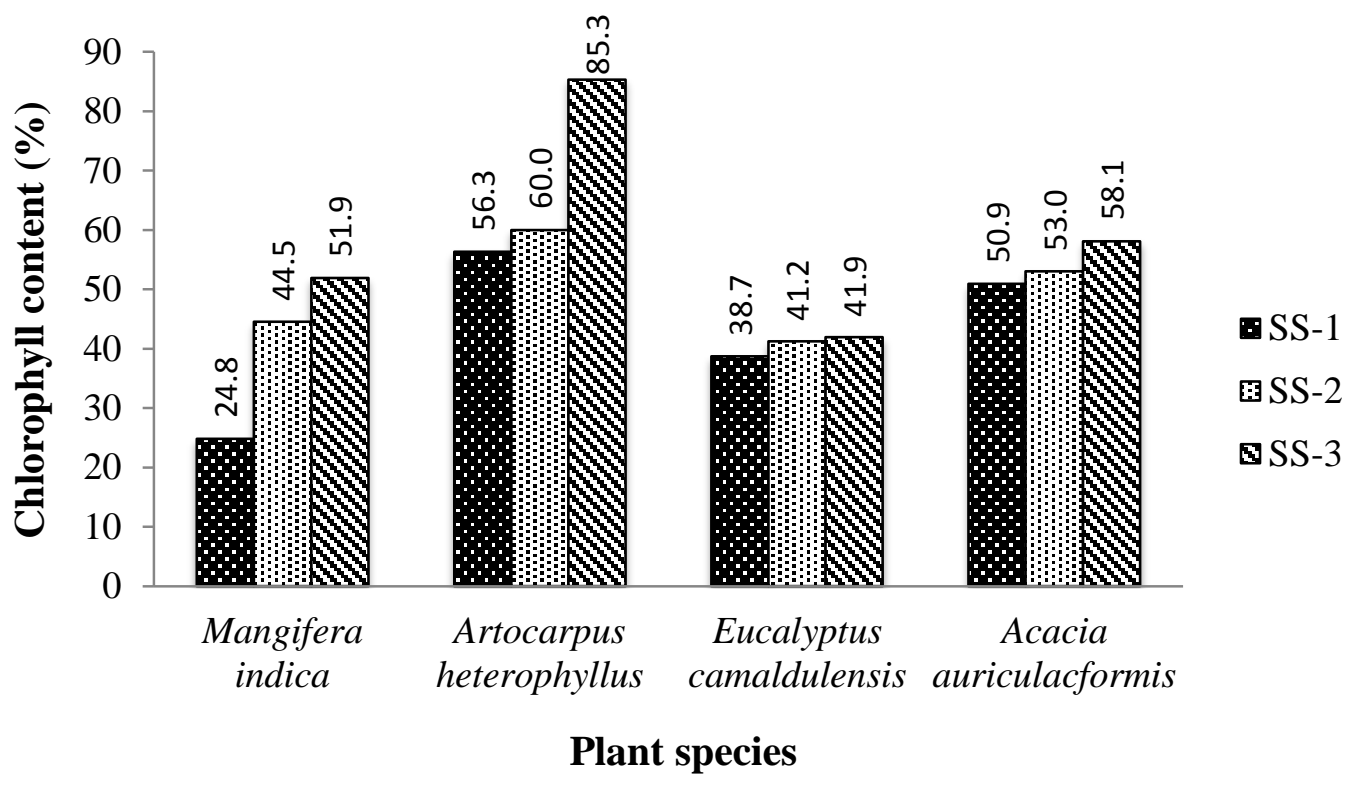

Fig. 2. Total chlorophyll content (\%) at three sampling stations.

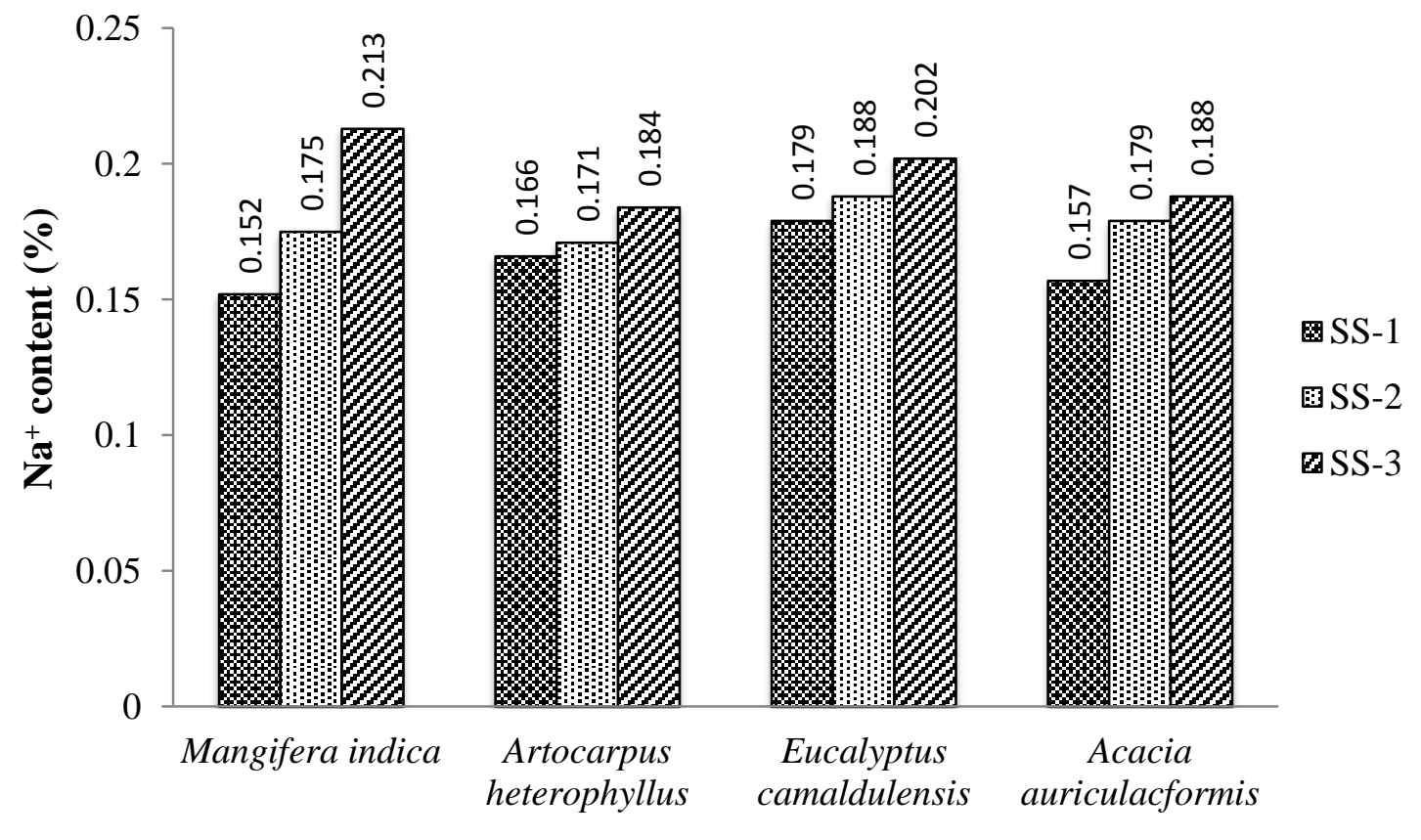

Plant species

Fig. 3. $\mathrm{Na}^{+}$content $(\%)$ at three sampling stations.

Potassium is the primary or major nutrients in plants are essential for the formation and transfer of carbohydrates in plants, and for photosynthesis and protein synthesis. The $\mathrm{K}^{+}$occurs particularly in the growing points, fruits, leafs and seeds of plants (Adeyeye, 
2005). The $\mathrm{O}_{3}$ significantly decreased $\mathrm{K}^{+}$ content of plants (Zheng et al., 2014). The study found that brick kiln induced air pollution affects the $\mathrm{K}^{+}$content of all plant species except Eucalyptus camaldulensis at SS-1 than at SS-3 ( $p=0.179 ; p>0.05)$. Among the examined plant species, the lowest $\mathrm{K}^{+}$content was found in Acacia auriculacformis at SS-1 and the highest was at SS-3, which exhibiting that this species is more susceptible to air pollution from the emission during brick kiln operation (Fig. 4).

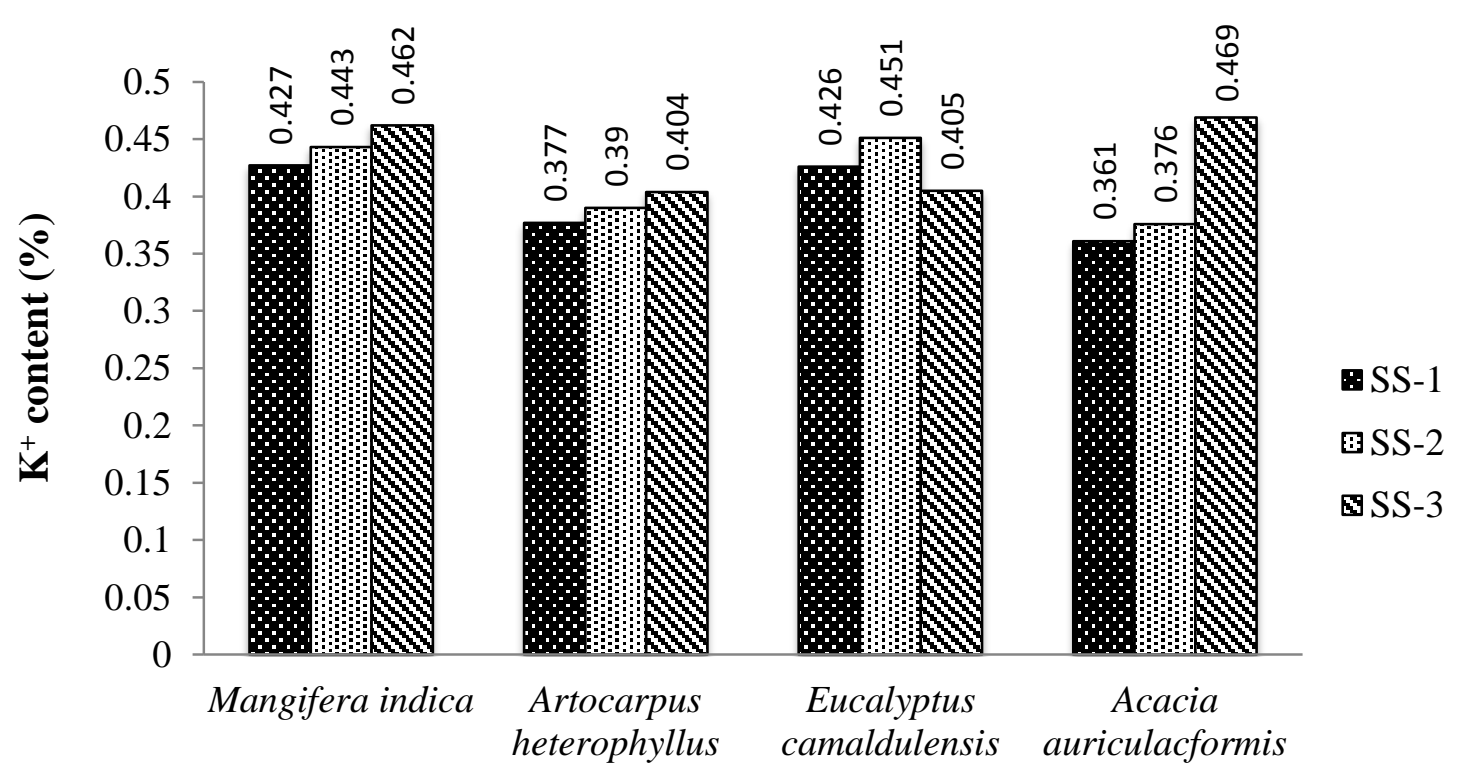

\section{Plant species}

Fig. 4. $\mathrm{K}^{+}$content (\%) at three sampling stations.

The $\mathrm{K}^{+} / \mathrm{Na}^{+}$ratio is the criteria which is the genetically approved for salt tolerance. So the varieties maintaining higher $\mathrm{K}^{+} / \mathrm{Na}^{+}$ratio are the salt tolerant and showing positive correlation between yield and $\mathrm{K}^{+} / \mathrm{Na}^{+}$ratio (Khan et al., 2009). The study demonstrated that $\mathrm{K}^{+} / \mathrm{Na}^{+}$ratio was decreased $(p=0.215$; $p>0.05$ ) in all plant species with increasing distance from the source of emission except Acacia auriculacformis species. The minimum value of $\mathrm{K}^{+} / \mathrm{Na}^{+}$ratio was found in Eucalyptus camaldulensis at SS-3, while the maximum value was observed in Mangifera indica at SS-1 (Fig. 5).

The decrease in total sugar content of damaged leaves probably corresponded with the photosynthetic inhibition or stimulation of respiration rate (Tzvetkova \& Kolarov, 1996). The total sugar content was reduced $(p=0.162 ; p>0.05)$ with increasing pollution load at SS-1 (near source station) for all the plant species than at SS-3 (distant station). Similar results were also found by some researchers that concentrations of total sugars decreased significantly in the 
sensitive trees to the air pollution (Seyyednejad \& Koochak, 2011). Among the examined plant species, Eucalyptus camaldulensis showed the lowest total sugar concentration at SS-1, while the highest were observed in Mangifera indica at SS-1. The results also showed that the exotic plant species were more susceptible to air pollution than native species at SS-1 (Fig. $6)$.

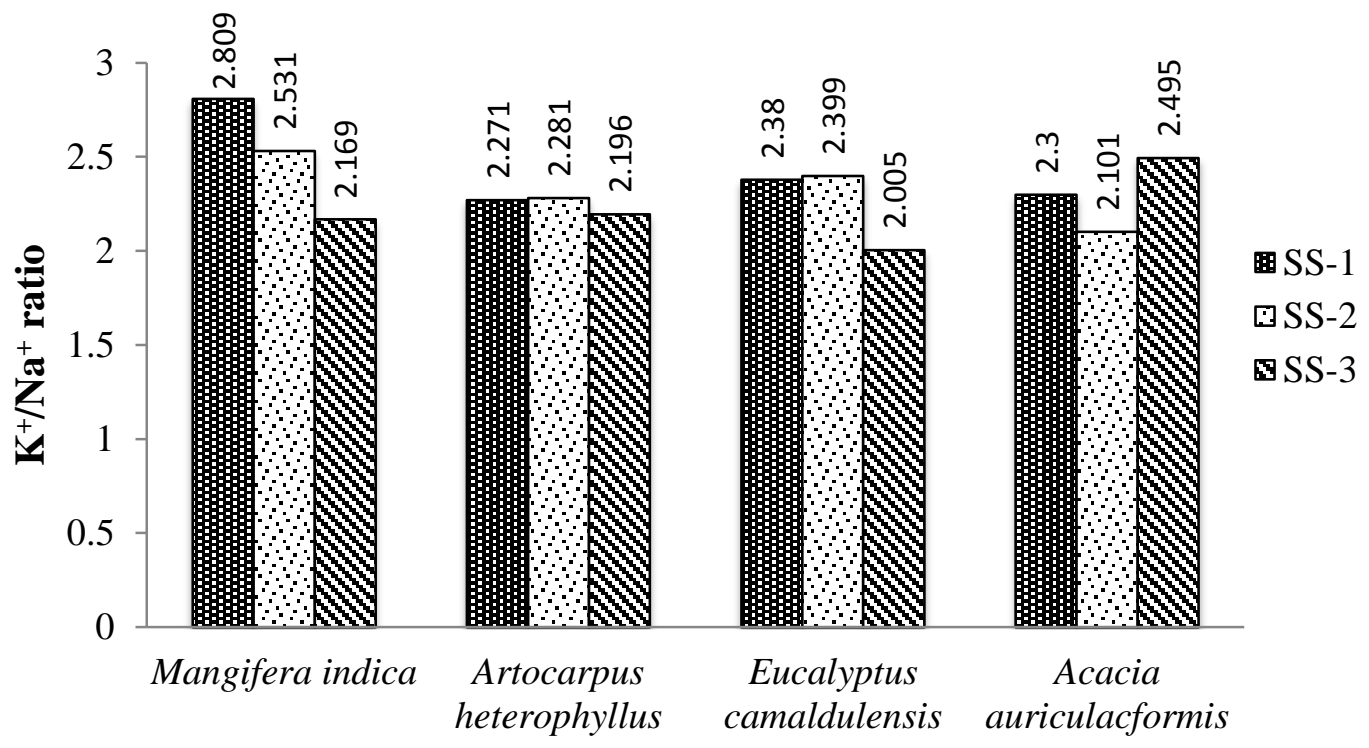

Plant species

Fig. 5. $\mathrm{K}^{+} / \mathrm{Na}^{+}$ratio at three sampling stations.

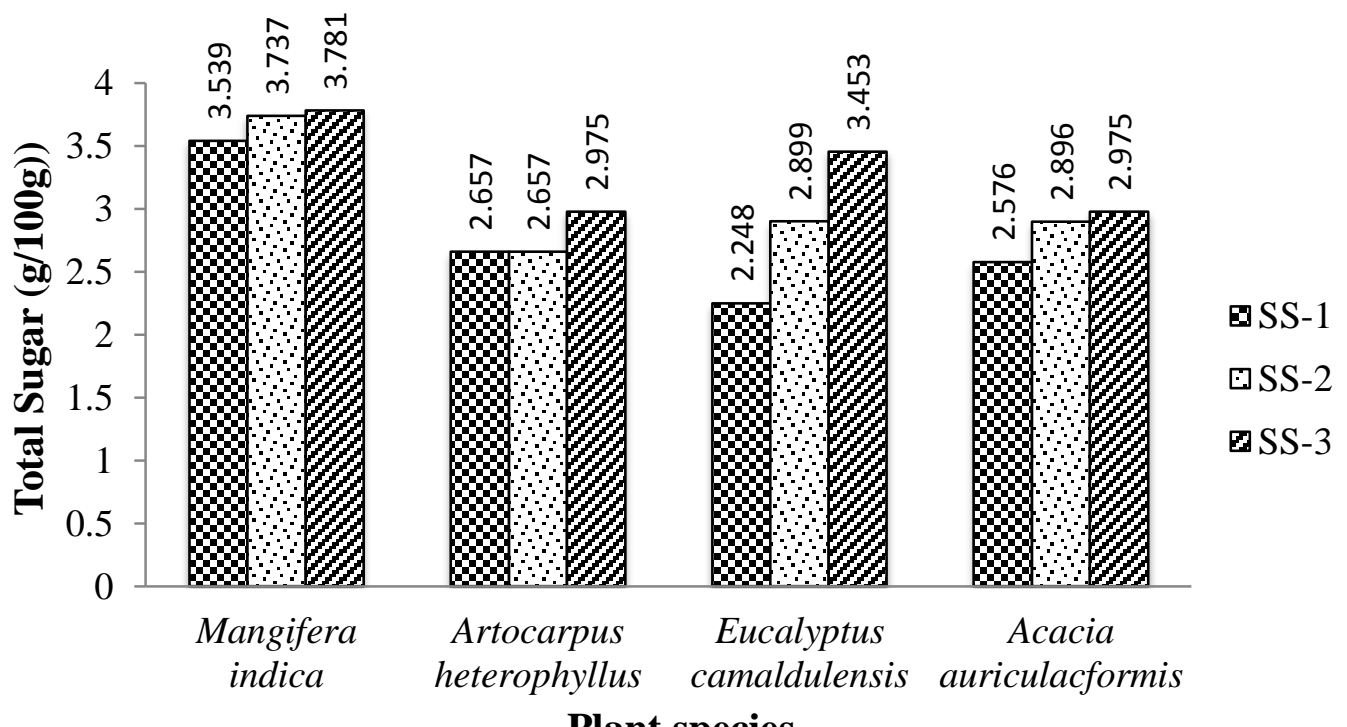

Fig. 6. Total sugar content $(\mathrm{g} / 100 \mathrm{~g})$ at three sampling stations. 
Proline is a universal osmolytic accumulated in response to several stress and may have a role in plant defense reactions (Khattab, 2007). Proline levels in polluted leaves act as protective mechanisms under air pollution stress, and also the plant make physiological adjustments to compensate for that environmental stress (Seyyednejad \& Koochak, 2011). The study investigated that the proline content was found to be depressed $(p=0.203 ; p>0.05)$ in the community inhabiting SS-1 including two indigenous sampled plant species than at SS-
3 while it was found to be increased in the proline content at SS-1 including two exotic sampled plant species than at SS-3. The increase of proline content in plants from polluted environment demonstrates good resistance and tolerance of plants to air pollution (Agbaire \& Akporhonor, 2014). Thus, the results of the study clearly depicted that indigenous plant species are more sensitive to air pollution, especially at near distance station, than exotic plant species (Fig. 7).

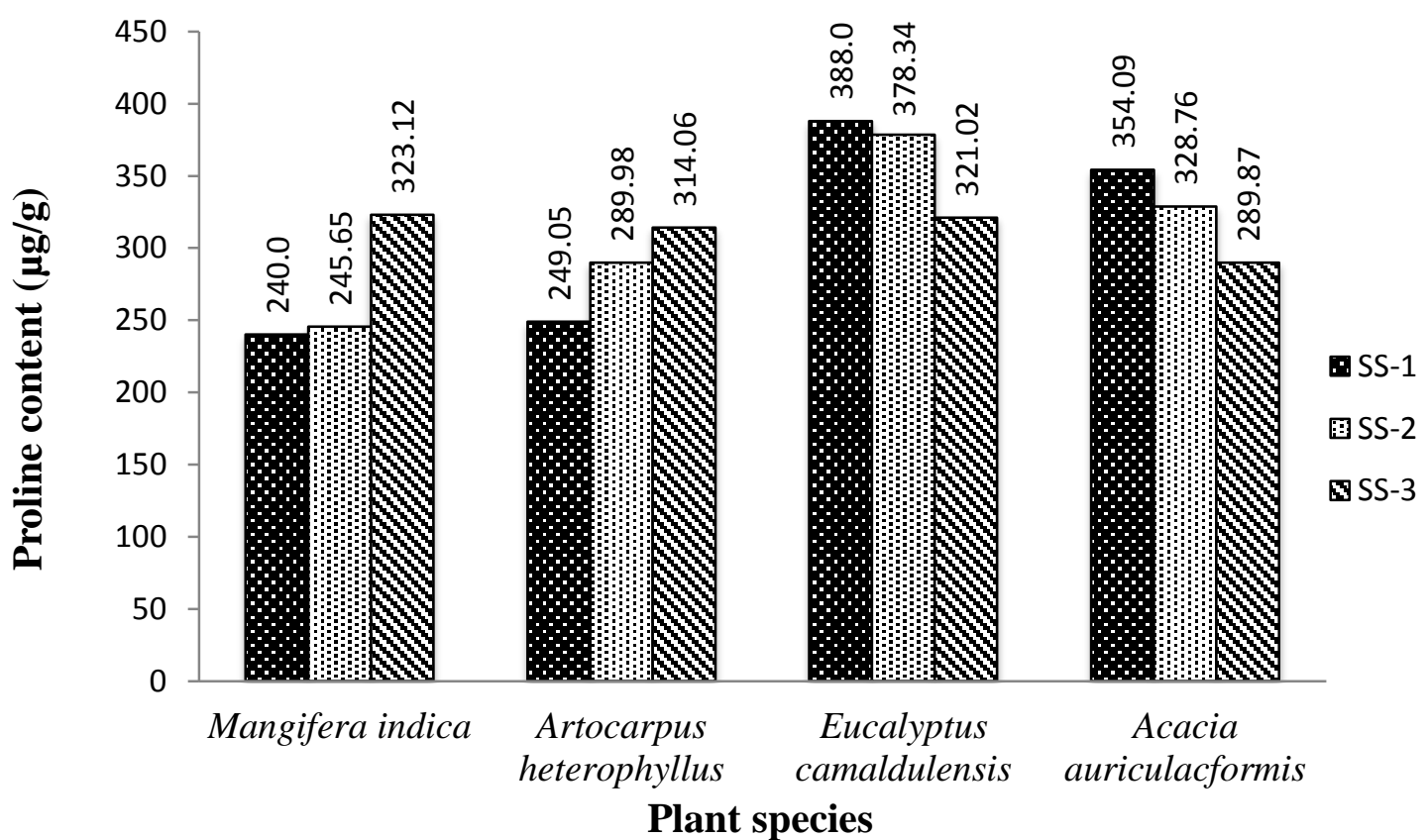

Fig. 7. Proline content $(\mu \mathrm{g} / \mathrm{g})$ at three sampling stations.

\section{CONCLUSIONS}

It is clear that the effects of brick kilns induced air pollutants can cause severe physiological changes in plant communities located at downwind locations. The study found that a reduction in total chlorophyll, $\mathrm{Na}^{+}, \mathrm{K}^{+}$(except Eucalyptus camaldulensis) and total sugar contents were observed for all plant species at the brick kiln periphery. 
Lower proline content was observed at kiln periphery in indigenous species, but higher in exotic species. Thus, the study concluded that in the case of most of the physiological parameters of indigenous plant species were more sensitive especially at near distance station (brick kiln periphery) than exotic plant species. In such condition, monitoring of existing kilns and installation of ecofriendly brick kiln maintaining the updated rules and regulations is necessarily important for minimizing the impacts of air pollution in the studied area.

\section{ACKNOWLEDGEMENTS}

Thanks to Mr. Boloram Karmaker, Student of the Department of Environmental Science and Resource Management, Mawlana Bhashani Science and Technology University, Tangail-1902, Bangladesh, for his kind cooperation during the sample collection.

\section{REFERENCES}

Adeyeye, EI. (2005). Distribution of major element $(\mathrm{Na}, \mathrm{K}, \mathrm{Ca}, \mathrm{Mg}$ ) in the various anatomical parts of fadama crops in Ekiti state, Nigeria. Chemical Society of Ethiopia 19(2): 175-183.

Agbaire, PO. \& Akporhonor, EE. (2014). The effects of air pollution on plants around the vicinity of the delta steel company, Ovwian-Aladja, Delta State, Nigeria. IOSR Journal of Environmental Science, Toxicology and Food Technology 8(7): 61-65.
Ahmed, S. \& Hossain, I. (2008). Applicability of air pollution modeling in a cluster of brickfields in Bangladesh. Chemical Engineering Research Bulletin 12: 28-34.

Ahmmed, KMT. \& Begum, DA. (2010). Air pollution aspects of Dhaka city. Proceedings of International Conference on Environmental Aspects of Bangladesh (ICEAB10), Japan. 129p.

Banglapedia. (2013). National Encyclopedia of Bangladesh, Asiatic Society of Bangladesh. [Retrieved from: http://en.banglapedia.org/index.php?t itle=Gazipur_Sadar_Upazila], Accessed on 02.07.2015.

Bates, LS., Waldren, RP. \& Teari, D. (1973). Rapid determination of free proline for water stress studies. Plant Soil 39: 205-207.

Chauhan, A. (2008). Effect of automobile and industrial air pollutants on some selected tree grown at the edge of road side in Haridwar. Journal of Natural and Physical Science 22(12): 37-47.

Chauhan, A. \& Joshi, PC. (2010). Effect of ambient air pollutants on wheat and mustard crops growing in the vicinity of urban and industrial areas. New York Science Journal 3(2): 5260.

Darain, KM., Rahman, ABMS., Ahsan, A., Islam, ABMS. \& Yusuf, B. (2013). Brick manufacturing practice in 
Bangladesh: A Review of Energy Efficacy and Air Pollution Scenarios. Journal of Hydrology and Environment Research 1(1): 60.

Fatima, I. (2011). Impact of brick kiln emissions on the ambient air quality and vegetation: A case study of district Budgam. M. Phil. dissertation, University of Kashmir.

GEF-UNDP (Global Environment FacilityUnited National Development Programme). (2006). Impact of brick kiln pollution on Dhaka City. Global Environment Facility- United National Development Programme study. [Retrieved from http://centers.iub.edu.bd/chpd/Pres_S em_Ijaz\%20Hossain_Aprl\%201708.pdf], Accessed on 02.03.2015.

Gupta, AK., Singh, P. \& Kumar, P. (2012). Evaluation of air pollution tolerance index of road side dominant herbs and trees at Varanasi (U.P.), India. Plant Archives 12: 1053-1055.

Hassan, M., Mumtaz, W., Raza, I., Syed, WAA. \& Ali, SS. (2012). Application of air dispersion model for the estimation of air pollutants from coal-fired brick-kilns samples in Gujrat. Science International (Lahore) 24(4): 141.

Kainulainen, P., Holopainen, JK. \& Okasanea, J. 1995. Effects of sulphur dioxide on the concentration of carbohydrates and secondary compounds in Scot pine (Pinus sylvestris L.) and Norway spruce
(Picea abies L.) seedlings. New Phytology 130: 231-238.

Katiyar, V. \& Dubey, PS. (2001). Sulphur dioxide sensitivity on two stage of leaf development in a few tropical tree species. Indian Journal of Environmental Toxicology 11: 78-81.

Khan, MA., Shirazi, MU., Muhammad, AK., Mujtaba, SM., Islam, E., Mumtaz, S., Shereen, A., Ansari, RU. \& Yasin, AM. (2009). Role of proline, K/Na ratioand chlorophyll content in salt tolerance of wheat. Pakistan Journal of Botany 41(2): 633-638.

Khattab, H. (2007). The defense mechanism of cabbage plant against phloemstucking aphid (Brevicoryne brassicae L.). Australasian Journal of Basic Applied Science 1: 56-62.

Liu, YJ. \& Ding, H. (2008). Variation in air pollution tolerance index of plants near a steel factory: implication for landscape-plant species selection for industrial areas. Wseas Transactions on Environment and Development 4: 24-32.

Maatoug, M. (2010). Cartographie de la pollution atmospherique par le plomb d' origine routiere a l'aide de transplantation d'un lichen bioaccumulateur Xanthoria parietina dans la ville de Tiaret (Algerie). Revue pollution atmospheric 205: 93-101.

Pathak, RK., Tomar, C., Neelumalviya \& Mahajan, S. (2015). Phytomonitoring of atmospheric pollution in road side 
perennial trees of Indore city (M.P.), India. International Journal of Advances in Engineering and Technology 7(6): 1727-1734.

Prakesh, G., Gupta, V., Poonia, S., Sangita \& Gupta, S. (2002). Effect of $\mathrm{SO}_{2}$ exposure on the chlorophyll contents in Raphanussativus L. and Brassicarapa L. Plant Archeology 2(2): 165-170.

Rahman, MM., Rahman, M., Guogang, Z. \& Islam, KS. (2010). A review of the present threats to tropical moist deciduous Sal (Shorea robusta) forest ecosystem of central Bangladesh. Journal of Tropical Conservation Science 3(1): 90-102.

Raza, SH. \& Murthy, MSR. (1988). Air pollution tolerance index of certain plants of Nacharam industrial area, Hyderabad. Indian Journal of Botany 11(1): 91-95.

Seyyednejad, SM. \& Koochak, H. (2011). A Study on air pollution-induced biochemical alterations in Eucalyptus camaldulensis. Australian Journal of Basic and Applied Science 5(3): 601-606.

Subbarao, GV., Ito, O., Berry, WL. \& Wheeler, RM. (2003). Sodium- A functional plant nutrient. Critical Reviews in Plant Sciences 22(5): 391-416.

Tzvetkova, N. \& Kolarov, D. (1996). Effect of air pollution on carbohydrate and nutrient concentrations in some deciduous tree species. Bulgarian
Journal of Plant Physiology 22: 5363.

UNDP (United Nations Development Program). (2011). Eco-friendly brick technique helps build a cleaner Bangladesh. UNDP study. [Retrieved from http://www.beta.undp.org/undp/en/h ome/presscenter/articles/2011/06/20/ eco-friendlybrick-technique-helpsbuild-a-cleaner-bangladesh.html], Accessed on 24/02/15.

WB (World Bank). (2007). Small study on air quality and impacts of the North Dhaka brickfield cluster by modeling of emissions and suggestions for mitigation measures including financing models. Consultant report prepared by Bangladesh University of Engineering and Technology for the World Bank, Washington DC.

WB (World Bank). (2010). Introducing Energy-Efficient Clean Technologies in the Brick Sector of Bangladesh, Report No. 60155-BD, Environment, Climate Change and Water Resource Unit, World Bank (WB), Washington DC.

Yadav, SK., Singh, MM. \& Kumar, V. 2013. Effect of air pollutants in biochemical parameters of selected plant species of Jhansi City (Uttar Pradesh). International Journal of Emerging Technologies in Computational and Applied Sciences 6(2): 168-173. 
Zheng, Y., Cheng, D. \& Simmons, M. (2014). Ozone pollution effects on gas exchange, growth and biomass yield of salinity-treated winter wheat cultivars. Science of the Total Environment 499: 18-26. 